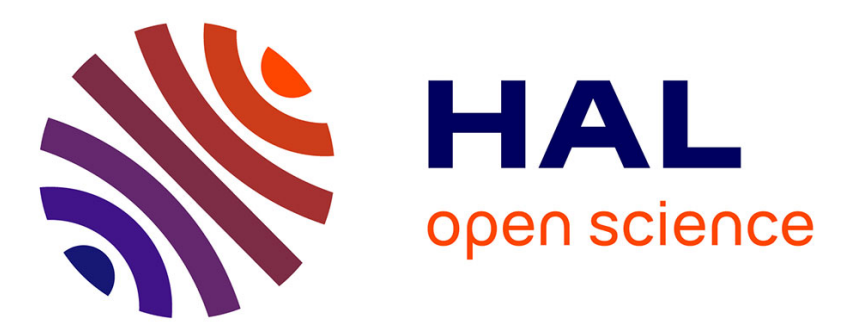

\title{
Natural and Unnatural A-secoTerpenes from Pulegone: Synthesis of Galbanic Acid and Marneral Revisited
} Andrei Corbu, Maurizio Aquino, Manuel Perez, Zoila Gandara, Siméon Arseniyadis

\section{- To cite this version:}

Andrei Corbu, Maurizio Aquino, Manuel Perez, Zoila Gandara, Siméon Arseniyadis. Natural and Unnatural A-secoTerpenes from Pulegone: Synthesis of Galbanic Acid and Marneral Revisited. European Journal of Organic Chemistry, 2009, 2009, pp.6386 - 6392. 10.1002/ejoc.200901021 . hal-03102194

\section{HAL Id: hal-03102194 \\ https://hal.science/hal-03102194}

Submitted on 7 Jan 2021

HAL is a multi-disciplinary open access archive for the deposit and dissemination of scientific research documents, whether they are published or not. The documents may come from teaching and research institutions in France or abroad, or from public or private research centers.
L'archive ouverte pluridisciplinaire HAL, est destinée au dépôt et à la diffusion de documents scientifiques de niveau recherche, publiés ou non, émanant des établissements d'enseignement et de recherche français ou étrangers, des laboratoires publics ou privés. 


\title{
Natural and Unnatural A-seco Terpenes from Pulegone: Synthesis of Galbanic Acid and Marneral Revisited
}

\author{
Andrei Corbu, ${ }^{[a]}$ Maurizio Aquino, ${ }^{[a]}$ Manuel Perez, ${ }^{[a]}$ Zoila Gandara, ${ }^{[a]}$ and \\ Siméon Arseniyadis*[a]
}

Keywords: Terpenoids / Natural products / Chiral pool / Mitsunobu etherification / Microwave chemistry

We describe herein an improved chiral-pool strategy for assembling the core structure 3 (both antipodes) of various Aseco terpenoids that have allowed us to prepare natural galbanic acid [(-)-1] from $(S)-(-)$-pulegone [(-)-2]. Furthermore, we were able to increase both the yield and step efficiency of the synthesis of marneral [(+)-7] as well as to access higher homologues of ent-galbanic acid [(+)-4], ent-secodrial [(+)-5], and bis-epi-secochiliotrin (6) from $(R)-(+)$-pulegone [(+)-2]. (○) Wiley-VCH Verlag GmbH \& Co. KGaA, 69451 Weinheim, Germany, 2009)

\section{Introduction}

A range of secondary metabolites contain a trans or cis vic-dimethyl-substituted six-membered ring along with two side-chains in various stereochemical combinations. We initiated a program based on a chiral-pool approach to the synthesis of selected targets (1 and $\mathbf{7 - 1 0}$, Scheme 1) that represent several families of naturally occurring A-seco terpenes that have in common a central B-ring nucleus with three adjacent stereogenic centers, one of which is a quaternary carbon atom, and a three-carbon oxygenated sidechain and an exocyclic dimethyl olefin. Galbanic acid [(-)1], ${ }^{[1]}$ a sesquiterpene coumarin ether, shows a range of biological activities, such as antibiotic, ${ }^{[2]}$ antibacterial, antithrombotic, ${ }^{[3]}$ and hepatoprotective activities. ${ }^{[4]}$ The compound is a potent antifertility and hormonal lead and it has also been demonstrated to synergize the activity of various antibiotics, ${ }^{[5]}$ opening up promising applications for the treatment of MRSA (methicillin-resistant Staphylococcus aureus) infections. ${ }^{[6]}$ Very recently, methyl galbanate $[(-)-18]$ and galbanic acid [(-)-1] were screened in an in vitro antiinfluenza $A$ viral $\left(\mathrm{H}_{1} \mathrm{~N}_{1}\right)$ assay with amantadine as a positive control. They are reported to show great potency against influenza $A$ virus $\mathrm{H}_{1} \mathrm{~N}_{1}\left(\mathrm{IC}_{50}=0.26\right.$ and $0.45 \mu \mathrm{g} /$ $\mathrm{mL}$, respectively), with the $\mathrm{C}-3$ methyl ester showing better potency than the corresponding free (galbanic) acid. ${ }^{[7]}$ The sesquiterpene-isofraxidin ether secodrial $(\mathbf{8})^{[8]}$ differs from $\mathbf{1}$ only by the presence of two methoxy groups on the aro-

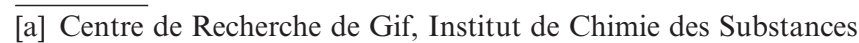
Naturelles, CNRS,

91198 Gif-sur-Yvette Cedex, France simeon.arseniyadis@icsn.cnrs-gif.fr

Supporting information for this article is available on the WWW under http://dx.doi.org/10.1002/ejoc.200901021. matic ring and the oxidation state at C-3. The indole isoprenoid suaveolindole (9), which shows activity against the Gram-positive bacteria Bacillus subtilis and methicillinresistant Staphylococcus aureus, ${ }^{[9]}$ and the hitherto not synthesized secochiliotrin (10 ${ }^{[10]}$ bear an indole- and a furancontaining side-chain, respectively, the latter belonging to the diterpene family (Scheme 1). Marneral ${ }^{[11]}[(+)-7]$, a monocyclic triterpene, which was hypothesized by Marner and co-workers to be the first carbocyclic precursor in the biosynthesis of triterpenoid iridals, ${ }^{[12]}$ shares the same relative B-ring stereochemistry as suaveolindole [(+)-9], galbanic acid [(-)-1], and secodrial [(-)-8] (though antipodal).
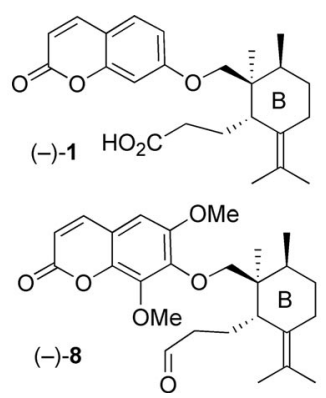
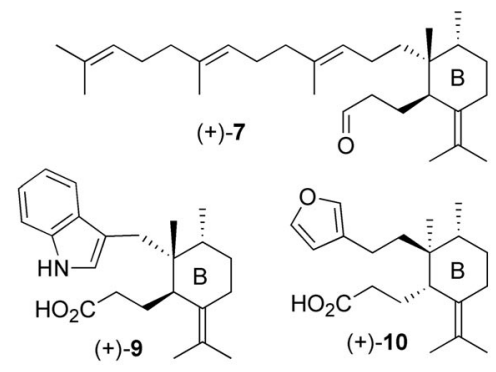

Scheme 1. Structures of representative A-seco terpenes bearing structurally similar B-ring moieties.

Recently we published the first synthesis of two structurally similar A-seco terpenes, ent-galbanic acid $[(+)-1]$ and marneral [(+)-7] from $(R)-(+)$-pulegone. ${ }^{[13]}$ The key feature of the synthetic route was a highly selective Claisen rearrangement that secured the stereochemical arrangement of both targets. This work allowed the determination of galbanic acid's absolute structure by comparison of the final 


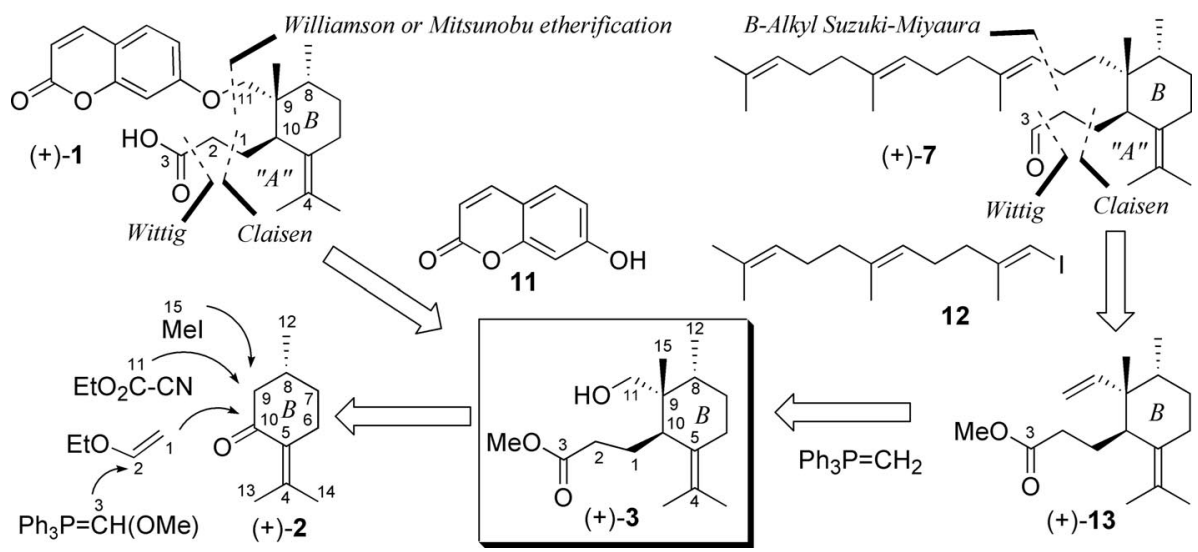

Scheme 2. Divergent synthesis of ent-galbanic acid and Marneral from the common intermediate (+)-3.

product with natural galbanic acid, ${ }^{[14]}$ thereby resolving the controversy regarding its relative stereochemistry. ${ }^{[15]} \mathrm{Be}-$ cause the absolute stereochemistry of natural galbanic acid $[(-)-1]$ has not been proven before, we first carried out the total synthesis by using the more accessible enantiomer $(R)$ pulegone. Starting from the key intermediate (+)-3, common to both targets and prepared in nine steps from $(R)$ $(+)$-pulegone, the targeted products (+)-1 and (+)-7 could be accessed by using the appropriate sequence of steps. The retrosynthetic scheme to which we were attracted involved the disconnection of the strategic bonds indicated in Scheme 2. Despite the inefficient segment coupling, the synthesis of the antipodal $\mathbf{1}$ in this work secured both the relative and absolute stereochemistry attributed to natural galbanic acid.

Although the quantities of ent-(+)-galbanic acid prepared by the above sequence were sufficient to complete the characterization of the target molecule, we were disappointed with the inefficiency of both the elaboration of the quaternary carbon center at C-9 and the segment coupling. We detail herein a full account of our results of the revised chiral-pool strategy that partially overcomes these problems while still permitting large-scale synthesis of the requisite trisubstituted cyclohexane framework 3 (both antipodes) for coupling with the aromatic partners and farnesyl chain precursors. In this work, the B-ring chiral fragment gains its asymmetry from $(S)-(-)$-pulegone for galbanic acid and from $(R)-(+)$-pulegone for an improved synthesis of marneral as well as galbanic acid, secodrial, and secochiliotrin analogues.

\section{Results and Discussion}

As described in our previous article, ${ }^{[13]}(-)-\mathbf{1 4}$ was obtained from (-)-2, but despite extensive experiments, the yield-decreasing enol carbonate formation during the first step could not be avoided. We therefore studied other alternatives with the hope that the C-9 quaternary center could be installed more efficiently. After further study, key intermediate $\mathbf{1 4}$ was more conveniently obtained by an alternative route simply by using ethyl cyanoformate instead of ethyl chloroformate as the C-9 side-chain precursor. Functional group manipulation of diol $\mathbf{1 4}$ derived from the three-step reaction sequence cleanly afforded the conveniently substituted cyclohexane skeleton found in target sesquiterpene frameworks. The three-step transformation of allyl alcohol 14 into the desired $\gamma, \delta$-unsaturated aldehyde 16 was achieved by a Claisen rearrangement ${ }^{[16]}$ and was followed by homologation of the aldehyde to furnish enol ether $\mathbf{1 7}$ in $90 \%$ yield as a mixture of $E / Z$ isomers, which was subsequently converted into the required ester 3 by using the Piancatelli protocol (Scheme 3). ${ }^{[17]}$ The targeted ester alcohol 3 (both antipodes) is a potentially flexible compound because it contains the requisite absolute chirality at C-8, C-9, and C-10, as well as appropriate functional handles for introducing the remaining substituents to complete the side-chains of sesquiterpene-coumarin ethers galbanic acid, secodriol, and higher homologues, as well as the A-seco triterpene marneral (7) and the diterpene bisepi-secochiliotrin (6).
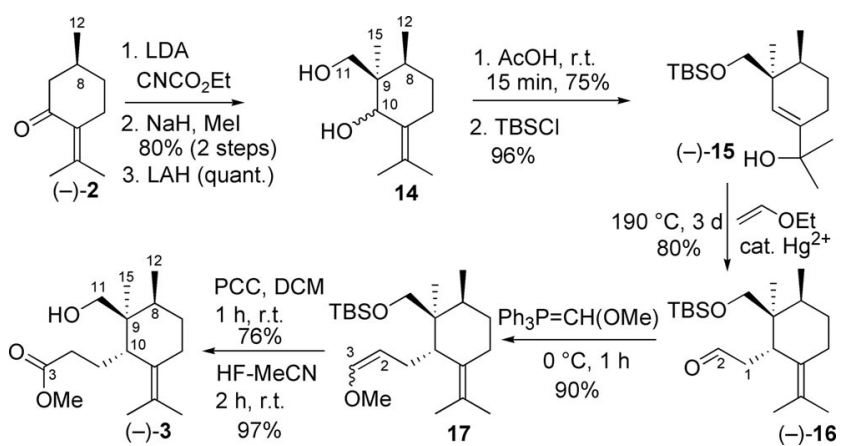

Scheme 3. Synthesis of the key intermediate (-)-3.

In our previous synthesis, coupling, though in very low yield, was carried out by treatment of commercially available umbelliferone (11) with the neopentylic tosylate obtained from (+)-3. Applying the Reymond protoco ${ }^{[18]}$ to the etherification in the presence of 18-crown- 6 under microwave irradiation gave (+)-18. Much effort was expended to generate the desired coumarin ether $\mathbf{1 8}$ in better yields by 


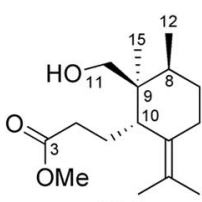

$(-)-3$

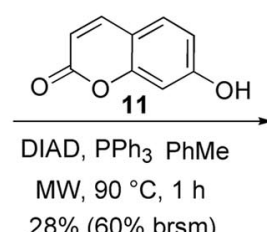

$28 \%(60 \%$ brsm)

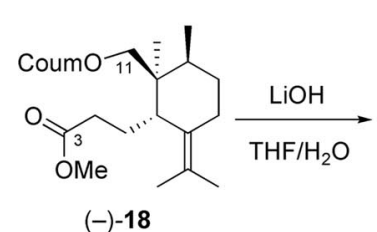

$(-)-18$

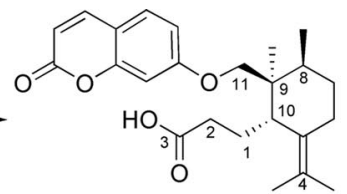

$(-)-1$

Scheme 4. Coumarin appendage by Mitsunobu etherification.

using different conditions (triflate instead of tosylate, higher temperatures, and longer microwave irradiation), but all failed. In the hope of overcoming the aforementioned difficulty, several other options were envisaged, and finally the Mitsunobu route (Scheme 4) was adopted. As expected, coupling of the precursor alcohol 3 with umbelliferone (11) under conventional Mitsunobu conditions (DIAD, $\mathrm{PPh}_{3}$, and $\mathrm{ROH})^{[19]}$ proved ineffective due to steric crowding, yielding only the starting materials. ${ }^{[20]}$ However, microwaveassisted ${ }^{[21]}$ coupling applying the Mitsunobu etherification conditions resulted in a clean transformation, affording the desired coupling of $\mathbf{1 1}$ and $\mathbf{3}$, although in a modest yield ( $28 \%$, along with $40 \%$ of recovered starting material). Nevertheless, this concise route allows for a rapid entry into coumarin sesquiterpene ether (-)-1 and constitutes the first synthesis of methyl galbanate [(-)-18], which is also a natural product and shows greater potency against influenza $\mathrm{A}$ virus $\mathrm{H}_{1} \mathrm{~N}_{1}$ than galbanic acid [(-)-1] and three-fold increased potency relative to that of amantadine. ${ }^{[7]}$

Note that the improved method reported here allows all three stereogenic centers of the precursor molecule $\mathbf{3}$ to be assembled with complete stereocontrol from pulegone in nine straightforward steps and, moreover, introduces chemoselectivity at the two desired sites (C-3/C-11). Although the preparation of the stereo-defined cyclic backbone was a simple undertaking, the most difficult part of the venture was the late-stage manipulation required to produce segment coupling $\alpha$ to a quaternary center. ${ }^{[22]}$

In view of the relevance of iridals as biologically active compounds, there still exists a need for the design of a practical route to marneral, the biogenetic precursor of all iridal representatives, with the ultimate goal to search for a chemobiological approach towards several members of the iridal family, mimicking Nature, and maximize flexibility with respect to analogue preparation. The common inter- mediate $(+)-3$, prepared on a large-scale using our improved route (this work), was elaborated to the alkylborane precursor (+)-13 by Swern oxidation and subsequent Wittig olefination. Having reached this stage it was expected that exposure of (+)-13 first to 9-BBN then to vinyl iodide $\mathbf{1 2}$ in the presence of the bis(diphenylphosphanyl)ferrocenepalladium(II) catalyst with the required co-ligand triphenylarsine and base would lead to the desired formation of marneric acid methyl ester (19) along with its reduced counterpart marnerol (20). Indeed, the $B$-alkyl Suzuki-Miyaura coupling, ${ }^{[23]}$ carried out according to the Johnson-Braun modification ${ }^{[24]}$ using 3 equiv. of 9-BBN provided marnerol (20) along with the corresponding carboxylic ester 19 in a 1.2:1 ratio, respectively. Attempts to increase the marnerol content of the reaction mixture by increasing the amount of 9-BBN or extending the reaction time were unsuccessful because a nearly unchanged ratio of ester 19 and alcohol $\mathbf{2 0}$ was reproducibly obtained. In the end, the ester was easily transformed into marnerol $[(+)-20]$ by a lithium aluminium hydride reduction. As portrayed in Scheme 5, direct coupling of the olefin ester (+)-13, obtained in 11 straightforward steps from $(R)-(+)$-pulegone, with the farnesyl chain precursor 12, paved the way for an improved enantioselective synthesis of marnerol [(+)-20] and marneral [(+)-7].

Our previously published approach was four steps longer, hampered by a sequence of protecting group modifications required by the series of operations that effected the conversion of (+)-21 into (+)-22 (Scheme 6). Apart from providing a highly convergent synthetic plan, the current protocol also offers the added benefit of sequence flexibility in the final stages of the synthesis. For example, a suitably functionalized B-ring segment could first be converted into (+)$\mathbf{2 2}$ or (+)-24 and then joined to the remaining farnesyl portion should problems be encountered in the original sequence of events.

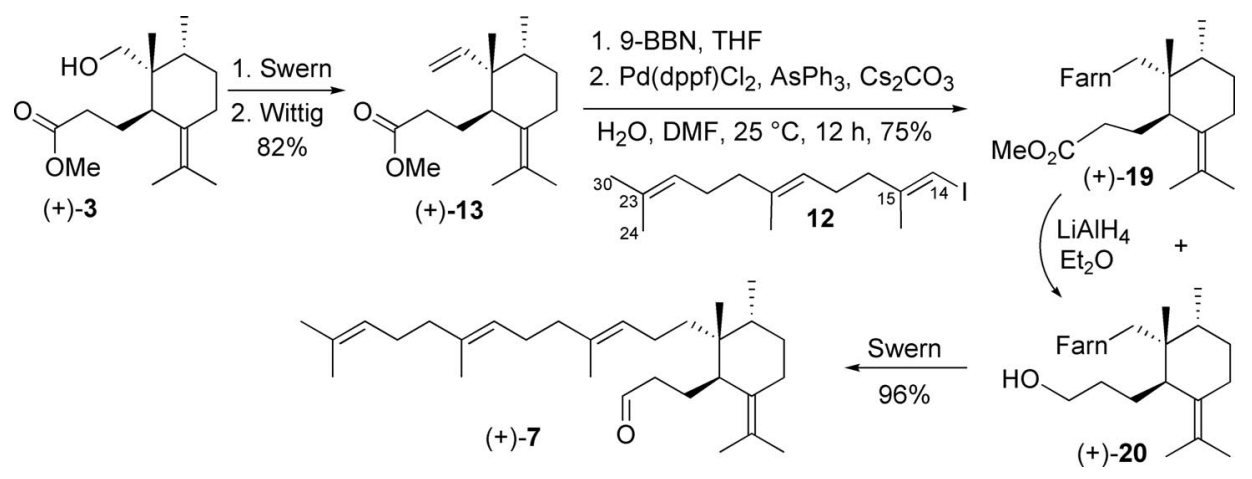

Scheme 5. Improved synthesis of marneral [(+)-3] (Farn represents the C13-C30 farnesyl chain, squalene numbering). 


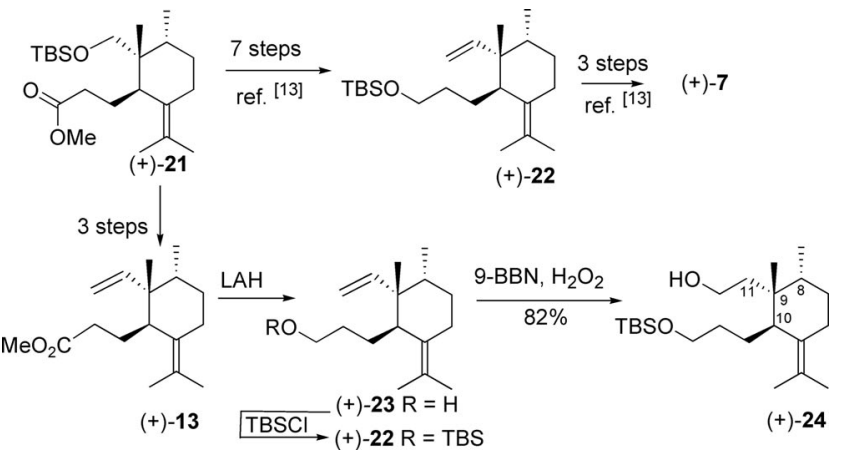

Scheme 6. Preparation of the coupling partners for iridals, homogalbanic acid, and homo-secodrial.

Through the success achieved in improving the marneral $[(+)-7]$ synthesis, the stage was set to test the planned bioconversion to the iridal parent molecule (+)-25 and several representatives of the iridal family (Scheme 7) with the ultimate goal to shorten our domino-based route ${ }^{[25]}$ by more than 10 linear steps before coupling. The characterization of cytochrome $\mathrm{P} 450$ in Iris rhizomes ${ }^{[26]}$ and the known reactivity of this monooxygenase towards the iridal parent molecule leading to 16-hydroxy-iridal, ${ }^{[27]}$ along with the recently reported bioinspired rigid iron catalyst $[\mathrm{Fe}(\mathrm{pdp})]{ }^{[28]}$ which could be used as a mimic of P450 enzymes, provides an insight that should help to define the guidelines for the possible routes to follow.

The availability of $(+)-7$ is encouraging, however, several of its precursor molecules of the type (+)-15x,y and (+)$11 x$ could well be substrates that bypass competition issues arising from the farnesyl side-chain. ${ }^{[29]}$

\section{Chiral-Pool-Derived Analogues}

With an effective preparation of (+)-13 in hand, it was a straightforward matter to convert it into the one-carbon homologated coupling partner $\mathbf{2 4}$ (Scheme 6) and assess its ability to meet our requirements. Thus, lithium aluminium hydride reduction followed by TBS protection and subsequent hydroboration/oxidation of the terminal olefin $(+)-\mathbf{1 3}$ afforded the C-11 homologated alcohol (+)-24, which served as a common intermediate for the synthesis of targeted analogues 4,5 , and $\mathbf{6}$. A variety of segment coupling protocols were screened as coupling proved to be more difficult than had been expected. Williamson etherification using the Reymond protoco ${ }^{[18]}$ with coumarin $\mathbf{1 1}$ and the tosylate corresponding to the precursor alcohol $\mathbf{2 4}$ was first tried as shown in Scheme 8, but proved fruitless. Most unexpected was the finding that the side-product $\mathbf{2 6}$ predominated, in contrast to the C-10 epimeric analogue, which un-

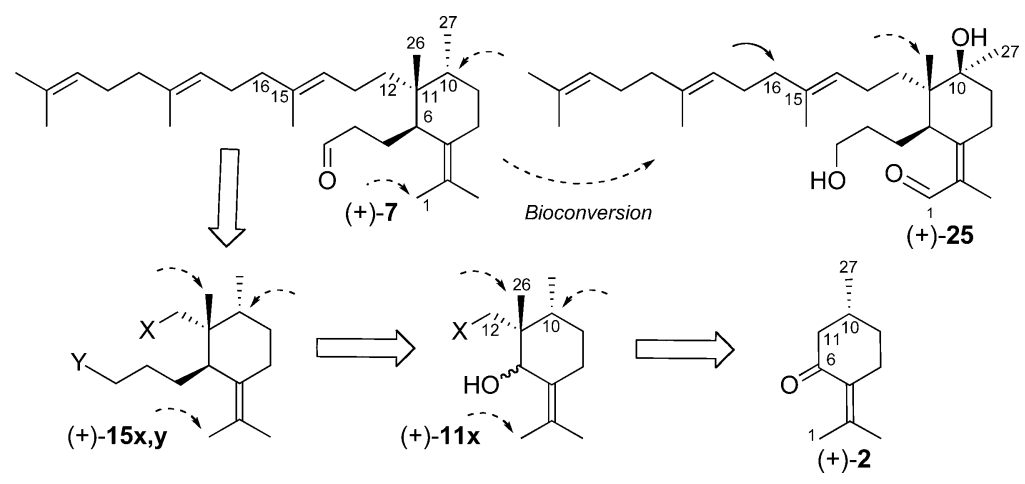

Scheme 7. Projected combined chiral-pool/chemobiological approach mimicking Nature (dashed arrows indicate desired oxygenation sites at any stage and the plain arrow refers to P450-mediated hydroxylation, as described in ref. ${ }^{[26]}$ ).

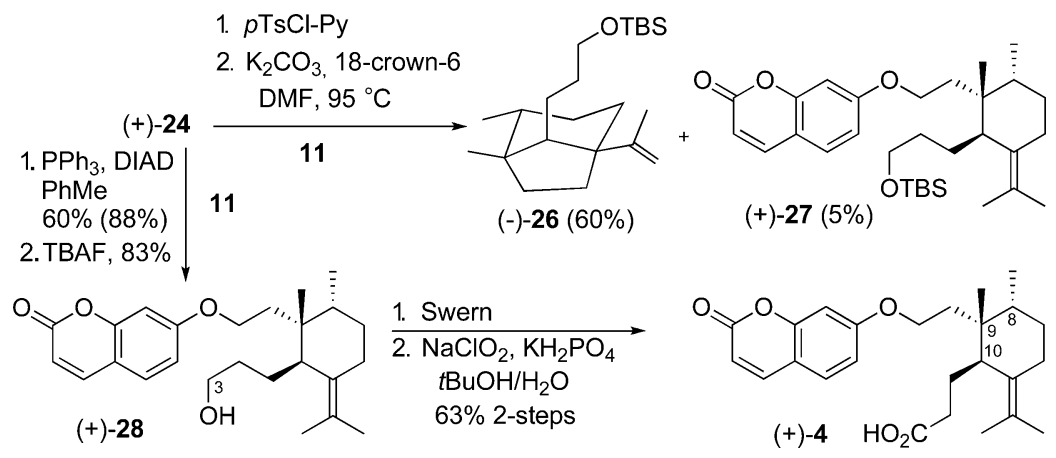

Scheme 8. Initial attempt to synthesize (+)-4 by Williamson etherification and the successful Mitsunobu coupling. 


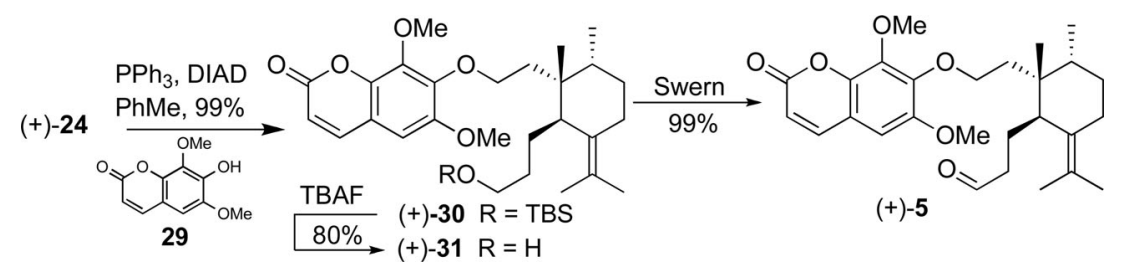

Scheme 9. Completion of the synthesis of the secodrial analogue (+)-26.

der the same conditions smoothly gave the corresponding coumarin ether (conversion of $\mathbf{2 5}$ to $\mathbf{2 6}$ in Scheme 7 of ref. ${ }^{[13]}$ ). As a result, the conventional Mitsunobu etherification was investigated, which afforded the desired adduct in good yields. We then completed the synthesis of the analogue (+)-4 by a fluoride-promoted deprotection and adjustment of the oxidation state at C-3 by using standard literature conditions.

Coupling of the homologated alcohol (+)-24 with the commercially available isofraxidin (29) under conventional Mitsunobu conditions (DIAD, $\mathrm{PPh}_{3}$, and $\mathrm{ROH}$ ) proceeded well, yielding a nearly quantitative yield of homo-secodriol precursor (+)-30. Deprotection of the TBS ether as above provided homo-secodriol $[(+)-31]$ in $80 \%$ yield, which was converted into homo-secodrial $[(+)-5]$ by Swern oxidation (Scheme 9).

In summary, although the congested Mitsunobu etherification of 3 with umbelliferone (11) (Scheme 4) needs further effort, both etherifications with isofraxidine (29) and umbelliferone (11) proceed nearly quantitatively to give the higher homologues of galbanic acid (1), secodriol (31), and secodrial (5), respectively.

Alongside the work just described, we also pushed towards a bis-epi-secochiliotrin analogue $\mathbf{6}$, which contains two adjacent stereogenic centers on the six-membered ring in the epimeric $9 R, 10 S$ disposition [required: $9 S, 10 R$ for natural secochiliotrin (10)], as summarized in Scheme 10. The assembly of the diastereomeric monocyclic diterpene secochiliotrin skeleton proceeds through the lithiation of 3bromofuran followed by addition to the aldehyde derived

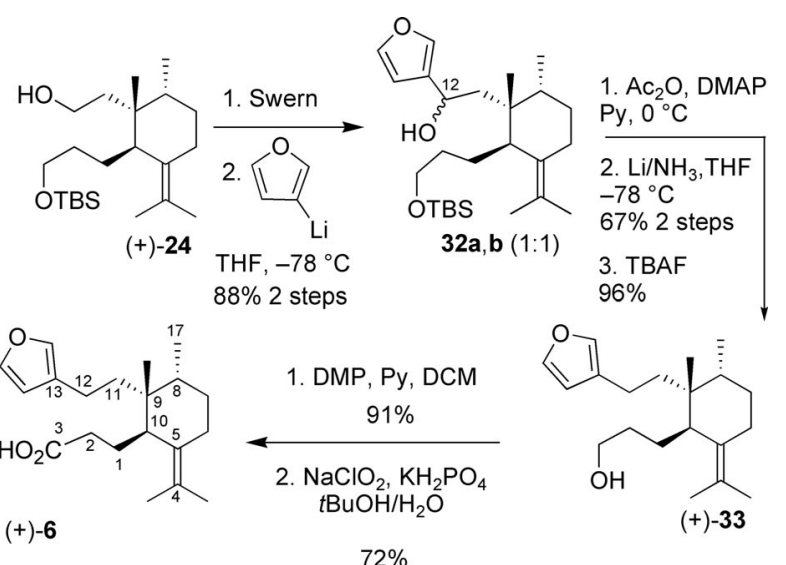

Scheme 10. Completion of the synthesis of diterpenoid bis-epi-secochiliotrin $[(+)-6]$. from the common B-ring unit $24 .^{[30]}$ The remaining steps consist of deoxygenation at $\mathrm{C}-12$ and readjustment of the oxidation state at $\mathrm{C}-3$.

The synthesis of (+)-6 was completed by the oxidation of the primary alcohol $\mathbf{3 3}$ with Dess-Martin periodinane (DMP) to yield the corresponding aldehyde, which in turn was converted into the required carboxylic acid in $65 \%$ yield from the alcohol. The synthetic scheme described herein represents a straightforward route to these compounds and the nonoptimized yields of the target molecules are good to high. Furthermore, the insignificant level of cytotoxicity (see Exp. Sect. in the Supporting Information) shown by all the synthesized products makes them potentially useful as biological probes.

\section{Conclusions}

The modified protocol reported herein allows the largescale synthesis of the key B-ring building block of various A-seco terpene frameworks in a step-efficient and stereocontrolled fashion. Our initial approach to introduce the C9 quaternary center was considerably improved by replacing ethyl chloroformate by ethyl cyanoformate. Even though the original obstacles associated with the segment coupling for the construction of galbanic acid still leave room for improvement, the synthetic scheme is general and broadens the scope of the chiral-pool-based sequence as a tool for the preparation of various natural and unnatural terpenoid ring systems in substantial enough amounts to support biological assays. Finally, the significant improvements in yield and step efficiency for the marnerol/marneral synthesis opens the way for a search aimed at raising the oxidation states on the ring (C-10, iridal numbering) and at C-26 and the olefinic methyl through hydroxylating enzymes.

\section{Experimental Section}

General: For general methods and standard procedures see the Supporting Information. Experimental descriptions for the synthesis of compounds (+)-13-(+)-18, (+)-1, and (+)-3 are available in the Supporting Information of our article on the ent-galbanic acid synthesis. ${ }^{[13]}$ Spectral data are identical to those obtained in the preparation of the unnatural enantiomers from $(R)$-pulegone.

Synthesis of Natural Galbanic Acid [(-)-1]: A microwave tube was charged with umbelliferone (11; $60 \mathrm{mg}, 0.37 \mathrm{mmol}),(-)-3$ (50 mg, $0.18 \mathrm{mmol}$ ), DIAD (75 mg, $0.37 \mathrm{mmol})$, and $\mathrm{PPh}_{3}$ (98 mg, $0.37 \mathrm{mmol})$ in toluene $(0.5 \mathrm{~mL})$ and the tube was inserted inside the microwave cavity. The reaction mixture was magnetically stirred 
for $30 \mathrm{~min}\left(P=100 \mathrm{~W}, T=130^{\circ} \mathrm{C}\right)$. The reaction mixture was evaporated and the resulting crude was purified by silica gel flash chromatography (heptane/EtOAc, 9:1) to yield $20 \mathrm{mg}$ (28\%) of methyl galbanate (-)-18, which was used in the saponification reaction directly. $\mathrm{LiOH}(6 \mathrm{mg}, 0.23 \mathrm{mmol})$ was added to a solution of methyl galbanate $[(-)-18 ; 19 \mathrm{mg}$. $0.046 \mathrm{mmol}]$ in $\mathrm{THF} / \mathrm{H}_{2} \mathrm{O}$ $(0.5 \mathrm{~mL} / 0.1 \mathrm{~mL})$. After stirring for $24 \mathrm{~h}$, the reaction was acidified to $\mathrm{pH} 2$ with $1 \mathrm{~N} \mathrm{HCl}$, extracted five times with EtOAc, and worked up as usual. The crude was purified by silica gel column chromatography (heptane/EtOAc, $1: 1)$ to yield $12 \mathrm{mg}(69 \%)$ of $(-)$-galbanic acid [(-)-1]. This compound was spectroscopically identical to the synthesized enantiomer, only the optical rotation was of the opposite sign. $[\alpha]_{\mathrm{D}}=-25\left(c=1.0, \mathrm{CHCl}_{3}\right){ }^{[13]}$

Methyl Marnerate (19): A solution of 9-BBN (2.6 mL, $0.5 \mathrm{M}$ in THF) was added to the ester olefin $13(111 \mathrm{mg}, 0.42 \mathrm{mmol})$ and the solution was stirred at $25^{\circ} \mathrm{C}$ for $2 \mathrm{~h}$. This solution was transferred by cannula to a separate flask containing a mixture of the vinyl iodide 12 (165 mg, $0.52 \mathrm{mmol}),\left[\mathrm{Pd}(\mathrm{dppf}) \mathrm{Cl}_{2}\right](34 \mathrm{mg}, 0.04 \mathrm{mmol})$, $\mathrm{AsPh}_{3}$ (19 mg, $\left.0.06 \mathrm{mmol}\right), \mathrm{Cs}_{2} \mathrm{CO}_{3}(410 \mathrm{mg}, 1.26 \mathrm{mmol}$ ), and water $(0.3 \mathrm{~mL}, 15.12 \mathrm{mmol})$ in DMF $(6 \mathrm{~mL})$. After $12 \mathrm{~h}$ the brown reaction mixture was diluted with water and extracted three times with diethyl ether. The organic layer was worked up as usual. The crude was purified by silica gel flash chromatography (heptane/ EtOAc, 99:1) to yield $74 \mathrm{mg}(41 \%)$ of $(+)-20$ and $65 \mathrm{mg}(34 \%)$ of (+)-19 as a colorless oil. $[\alpha]_{\mathrm{D}}=85\left(c=1.0, \mathrm{CHCl}_{3}\right)$. IR (film): $\tilde{\mathrm{v}}=$ 2960, 2916, 2857, 1739, 1434, 1372, 1255, 1166, 726, $696 \mathrm{~cm}^{-1} \cdot{ }^{1} \mathrm{H}$ NMR (500 MHz, $\left.\mathrm{CDCl}_{3}\right): \delta=0.71(\mathrm{~d}, J=6.7 \mathrm{~Hz}, 3 \mathrm{H}), 0.86(\mathrm{~s}, 3$ $\mathrm{H}), 0.98-1.05(\mathrm{~m}, 1 \mathrm{H}), 1.17-1.31(\mathrm{~m}, 2 \mathrm{H}), 1.37-1.43(\mathrm{~m}, 1 \mathrm{H})$, $1.51(\mathrm{~s}, 3 \mathrm{H}), 1.54(\mathrm{~s}, 6 \mathrm{H}), 1.60(\mathrm{~s}, 3 \mathrm{H}), 1.62(\mathrm{~s}, 3 \mathrm{H}), 1.68(\mathrm{~s}, 3$ H), $1.52(\mathrm{~d}, J=1.9 \mathrm{~Hz}, 3 \mathrm{H}), 1.61(\mathrm{~d}, J=1.1 \mathrm{~Hz}, 3 \mathrm{H}), 1.69-1.82$ $(\mathrm{m}, 6 \mathrm{H}), 1.86-2.02(\mathrm{~m}, 4 \mathrm{H}), 2.39(\mathrm{~m}, 1 \mathrm{H}), 2.50(\mathrm{dd}, J=4.8$, $11.1 \mathrm{~Hz}, 1 \mathrm{H}), 3.58(\mathrm{~s}, 3 \mathrm{H}), 4.85(\mathrm{~m}, 3 \mathrm{H}) \mathrm{ppm} .{ }^{13} \mathrm{C} \mathrm{NMR}$ $\left(125 \mathrm{MHz} \mathrm{CDCl}_{3}\right): \delta=15.6,15.9,16.0,17.6,20.2,20.7,22.3,22.5$, 24.2, 24.7, 25.7, 26.6, 26.7, 29.7, 30.9, 32.2, 36.1, 39.0, 39.7, 43.8, $51.3,124.2,124.4,125.5,130.8,131.1,134.2,133.7,134.2,134.8$, 174.7 ppm. MS (ESI, $\left.\mathrm{MeOH}+\mathrm{CH}_{2} \mathrm{Cl}_{2}\right): \mathrm{m} / z(\%)=479.4(100)$ $[\mathrm{M}+\mathrm{Na}]^{+}$. HRMS (ESI): calcd. for $\mathrm{C}_{31} \mathrm{H}_{52} \mathrm{O}_{2} \mathrm{Na} 479.3865$; found 479.3869 .

Homogalbanic Acid (4): Oxalyl chloride $(0.17 \mathrm{~mL}, 2 \mathrm{~m}$ in DCM, $0.34 \mathrm{mmol})$ was added to a solution of dry DMSO $(0.05 \mathrm{~mL}$, $0.68 \mathrm{mmol})$ in dry DCM $(3 \mathrm{~mL})$ at $-60^{\circ} \mathrm{C}$ under argon. The mixture was stirred for $30 \mathrm{~min}$ and a solution of the primary alcohol (+)-28 (45 mg, $0.11 \mathrm{mmol})$ in dry DCM $(1 \mathrm{~mL})$ was added. Upon $1 \mathrm{~h}$ of additional stirring at $-60^{\circ} \mathrm{C}, \mathrm{Et}_{3} \mathrm{~N}(0.15 \mathrm{~mL})$ was added and the mixture was warmed to $0{ }^{\circ} \mathrm{C}$, stirred for a further $20 \mathrm{~min}$, and poured into ice-cold water, diluted with DCM, washed with $1 \mathrm{~N}$ $\mathrm{HCl}$ and aqueous saturated $\mathrm{NaHCO}_{3}$, and worked up as usual. The crude obtained was used directly in the next oxidation step. 2Methylbut-2-ene $(0.12 \mathrm{~mL}, 1.13 \mathrm{mmol})$ and a solution of $\mathrm{NaClO}_{2}$ $(13 \mathrm{mg}, 0.15 \mathrm{mmol})$ and $\mathrm{KH}_{2} \mathrm{PO}_{4}(20 \mathrm{mg}, 0.15 \mathrm{mmol})$ in water $(0.5 \mathrm{~mL})$ were added to a solution of the previously obtained aldehyde in $t \mathrm{BuOH}(1 \mathrm{~mL})$. The reaction mixture was stirred for $12 \mathrm{~h}$ at $25^{\circ} \mathrm{C}$ and was finally quenched with brine and extracted four times with EtOAc. The organic layer was worked up as usual. The crude obtained was purified by silica gel flash chromatography (heptane/EtOAc, 2:1) to yield $29 \mathrm{mg}$ (63\% over two steps) of the acid (+)-4 as a glassy solid. $[\alpha]_{\mathrm{D}}=7\left(c=1.0, \mathrm{CHCl}_{3}\right)$. IR (film): $\tilde{v}$ $=3210,1734,1702,1610,1278,1229,1121,1011,833,753 \mathrm{~cm}^{-1}$. ${ }^{1} \mathrm{H}$ NMR $\left(500 \mathrm{MHz}, \mathrm{CDCl}_{3}\right): \delta=0.83(\mathrm{~d}, J=6.9 \mathrm{~Hz}, 3 \mathrm{H}), 1.03$ $(\mathrm{s}, 3 \mathrm{H}), 1.20-1.24(\mathrm{~m}, 1 \mathrm{H}), 1.45-1.50(\mathrm{~m}, 1 \mathrm{H}), 1.60(\mathrm{dt}, J=7.6$, $14.0 \mathrm{~Hz}, 1 \mathrm{H}), 1.66(\mathrm{~d}, J=1.5 \mathrm{~Hz}, 3 \mathrm{H}), 1.70(\mathrm{~s}, 3 \mathrm{H}), 1.76-1.90$ (m, $5 \mathrm{H}), 2.12-2.26(\mathrm{~m}, 2 \mathrm{H}), 2.51$ (br. d, $J=14.0 \mathrm{~Hz}, 1 \mathrm{H}), 2.59$ (dd, $J=4.61,11.5 \mathrm{~Hz}, 1 \mathrm{H}), 4.03$ (dd, $J=7.1,8.1 \mathrm{~Hz}, 2 \mathrm{H}$ ), 6.24 (d, $J=9.4 \mathrm{~Hz}, 1 \mathrm{H}), 6.79-6.82(\mathrm{~m}, 2 \mathrm{H}), 7.35(\mathrm{~d}, J=8.5 \mathrm{~Hz}, 1 \mathrm{H})$, $7.63(\mathrm{~d}, J=9.5 \mathrm{~Hz}, 1 \mathrm{H}) \mathrm{ppm} .{ }^{13} \mathrm{C} \mathrm{NMR}\left(125 \mathrm{MHz}, \mathrm{CDCl}_{3}\right): \delta=$ 15.6, 20.2, 20.7, 22.2, 24.1, 24.6, 30.8, 30.9, 31.9, 36.0, 38.8, 44.9, $66.3,101.3,112.4,112.9,113.0,125.6,128.7,130.3,143.4,155.9$, 161.3, 162.4, 179.7 ppm. MS (ESI, $\left.\mathrm{MeOH}+\mathrm{CH}_{2} \mathrm{Cl}_{2}\right): \mathrm{m} / z(\%)=$ $435.2(100)[\mathrm{M}+\mathrm{Na}]^{+}$. HRMS (ESI): calcd. for $\mathrm{C}_{25} \mathrm{H}_{32} \mathrm{O}_{5} \mathrm{Na}$ 435.2147; found 435.2153 .

Bis-epi-secochiliotrin [(+)-6]: Dess-Martin periodinane (DMP, $136 \mathrm{mg}, 0.32 \mathrm{mmol}$ ) was added to a solution of the alcohol (+)-33 $(33 \mathrm{mg}, 0.11 \mathrm{mmol})$ in DCM $(0.5 \mathrm{~mL})$ and pyridine $(0.1 \mathrm{~mL})$ and the reaction mixture was stirred for $1 \mathrm{~h}$. The solution was diluted with heptane (white precipitate appeared) and the suspension was subjected directly to column chromatography (heptane/EtOAc, 14:1) to yield $30 \mathrm{mg}(91 \%)$ of the desired aldehyde. 2-Methylbut-2ene $(0.11 \mathrm{~mL}, 0.99 \mathrm{mmol})$ and a solution of $\mathrm{NaClO}_{2}(12 \mathrm{mg}$, $0.13 \mathrm{mmol})$ and $\mathrm{KH}_{2} \mathrm{PO}_{4}(18 \mathrm{mg}, 0.13 \mathrm{mmol})$ in water $(0.5 \mathrm{~mL})$ were added to a solution of the aldehyde thus obtained in $t \mathrm{BuOH}$ $(0.2 \mathrm{~mL})$. The reaction mixture was stirred for $12 \mathrm{~h}$ at $25^{\circ} \mathrm{C}$ and was finally quenched with brine and extracted four times with EtOAc. The organic layer was worked up as usual. The crude obtained was purified by silica gel flash chromatography (heptane/ EtOAc, $4: 1)$ to yield $22 \mathrm{mg}(72 \%)$ of the acid (+)-6 as a colorless oil. $[a]_{\mathrm{D}}=38\left(c=1.0, \mathrm{CHCl}_{3}\right)$. IR (film): $\tilde{\mathrm{v}}=3391$ (b), 1706, 1452, 1374, 1259, 1025, 873, $801 \mathrm{~cm}^{-1} .{ }^{1} \mathrm{H}$ NMR $\left(500 \mathrm{MHz}, \mathrm{CHCl}_{3}\right): \delta=$ $0.79(\mathrm{~d}, J=6.6 \mathrm{~Hz}, 3 \mathrm{H}), 0.97(\mathrm{~s}, 3 \mathrm{H}), 1.20(\mathrm{qd}, J=4.5,13.2 \mathrm{~Hz}$, $1 \mathrm{H}), 1.28-1.33(\mathrm{~m}, 1 \mathrm{H}), 1.39-1.44(\mathrm{~m}, 1 \mathrm{H}), 1.48-1.55(\mathrm{~m}, 1 \mathrm{H})$, 1.68 (br. s, $6 \mathrm{H}), 1.75-1.81$ (m, $2 \mathrm{H}), 1.83-1.90$ (m, $2 \mathrm{H}$ ), 2.12-2.24 (m, $2 \mathrm{H}), 2.27-2.31$ (m, $2 \mathrm{H}), 2.47$ (br. d, $J=14.5 \mathrm{~Hz}, 1 \mathrm{H}), 2.66$ (dd, $J=4.8,11.5 \mathrm{~Hz}, 1 \mathrm{H}), 6.21(\mathrm{~s}, 1 \mathrm{H}), 7.17$ (s, $1 \mathrm{H}), 7.33$ (s, 1 H) ppm. ${ }^{13} \mathrm{C}$ NMR $\left(125 \mathrm{MHz}, \mathrm{CHCl}_{3}\right): \delta=15.56,19.3,20.2,20.8$, $22.3,24.0,24.7,30.9,31.9,32.5,36.1,39.2,43.8,111.0,124.9$, 126.1, 130.6, 138.4, 142.6, 178.9 ppm. MS (ESI, MeOH): $\mathrm{m} / z(\%)$ $=317.2(100)[\mathrm{M}-\mathrm{H}]^{+}$. HRMS (ESI, MeOH): calcd. for $\mathrm{C}_{20} \mathrm{H}_{29} \mathrm{O}_{3}$ 317.2117; found 317.2113.

Supporting Information (see also the footnote on the first page of this article): Complete characterization data and ${ }^{1} \mathrm{H}$ and ${ }^{13} \mathrm{C}$ NMR spectra for compounds $3,13,6$, and 19-33.

\section{Acknowledgments}

Financial support from the Centre National de la Recherche Scientifique (CNRS) and fellowship awards from the Institut de Chimie des Substances Naturelles (ICSN) are gratefully acknowledged.

[1] a) For the structure and stereochemistry of galbanic acid from galbanum, see: V. Y. Bagirov, V. I. Sheichenko, N. V. Veselovskaya, Y. E. Sklyar, A. A. Savina, I. Kir'yanova, Khim. Prir. Soedin. 1980, 16, 620-623; for the isolation from asafetida, see: b) G. Appendino, S. Tagliapietra, G. Nano, J. Jakupovic, Phytochemistry 1994, 35, 183-186; c) G. Appendino, L. Maxia, M. Bascope, P. J. Houghton, G. Sanchez-Duffhues, E. Muñoz, O. Sterner, J. Nat. Prod. 2006, 69, 1101-1104; d) G. Appendino, in: Virtual activity, real pharmacology (Ed.: L. Verotta), Trivandrum, 1997, pp. 1-15.

[2] a) S. K. Racnicer, J. Veeravally, Chem. Ind. (London) 1975, 12, 431; b) A. F. Artamonov, K. A. Nusipbekova, F. S. Nigmatullina, B. Z. Dzhienbaev, Chemistry of Natural Compounds, vol. 33 , no. 2, 1997, pp. 162-164

[3] During in vitro experiments galbanic acid suppressed the development of platelet aggregation induced by ADP, thrombin, histamine, adrenaline, acetylcholine, and collagen at concentrations of 50,100, and $200 \mu \mathrm{g} / \mathrm{mL}$. M. M. Mansurov, M. S. Martirosov, Farmakol. Toksikol. 1990, 53, 51-53. 
[4] V. N. Syrov, Z. A. Khushbactova, A. N. Nabiev, Farmakol. Toksikol. 1990, 53, 41.

[5] A. R. Shahverdi, A. Fakhimi, G. Zarrini, G. Dehghan, M. Iranshahi, Biol. Pharm. Bull. 2007, 30, 1805-1807.

[6] E. A. Bancroft, JAMA J. Am. Med. Assoc. 2007, 298, 18031804.

[7] C. L. Lee, L. C. Chiang, L. H. Cheng, C. C. Liaw, M. H. Abd El-Razek, F. R. Chang, Y. C. Wu, J. Nat. Prod. DOI: 10.1021/ np900158f.

[8] a) O. Hofer, W. Weissensteiner, M. Widhalm, Monatsh. Chem. 1983, 114, 1399-1411; b) H. Greger, O. Hofer, W. Robien, Phytochemistry 1983, 22, 1997-2003.

[9] a) H. D. Yoo, P. A. Cremin, L. Zeng, E. Garo, C. T. Williams, C. M. Lee, M. G. Goering, M. Oneil-Johnson, G. R. Eldridge, J. F. Hu, J. Nat. Prod. 2005, 68, 122-124; b) E. J. Velthuisen, S. J. Danishefsky, J. Am. Chem. Soc. 2007, 129, 10640-10641.

[10] J. Jakupovic, S. Banerjee, F. Bohlmann, R. M. King, Tetrahedron 1986, 42, 1305-1313.

[11] Matsuda et al. named this compound marneral (and its corresponding alcohol $\mathbf{3 b}$ marnerol) in recognition of the pioneering work of Marner on iridals. Compound $\mathbf{3}$ has never been isolated but was hypothesized to be the first carbocyclic precursor in the biosynthesis of iridals. Q. Xiong, W. K. Wilson, S. Matsuda, Angew. Chem. Int. Ed. 2006, 45, 1285-1288.

[12] a) F.-J. Marner, Curr. Org. Chem. 1997, 1, 153-186; b) F.-J. Marner, T. Kasel, J. Nat. Prod. 1995, 58, 319-323; c) M. Lamshöft, H. Schmickler, F.-J. Marner, Eur. J. Org. Chem. 2003, 727-733; d) F.-J. Marner, I. Longerich, Liebigs Ann. Chem. 1992, 269-272; e) A. Littek, F.-J. Marner, Helv. Chim. Acta 1991, 74, 2035-2042; f) F.-J. Marner, W. Krick, B. Gellrich, L. Jaenicke, W. Winter, J. Org. Chem. 1982, 47, 25312538.

[13] A. Corbu, M. Perez, M. Aquino, P. Retailleau, S. Arseniyadis, Org. Lett. 2008, 10, 2853-2856.

[14] We thank Professor Giovanni Appendino, Università del Piemonte Orientale, Novara, for supplying natural galbanic acid and for helpful discussion.

[15] The original assignment made by Bagirov ${ }^{[1 a]}$ was later revised by Lee who proposed an alternative structure, reversing the relative configurations at C8 and C9: S.-G. Lee, S. Ryu, J. W. Ahn, Bull. Korean Chem. Soc. 1998, 19, 384-386.

[16] The construction of a functionalized six-membered ring by conversion of an allylic alcohol into an allyl-vinyl-substituted ether followed by subsequent Claisen rearrangement was first reported by Ireland et al. in the early eighties: R. E. Ireland, M. D. Varney, J. Org. Chem. 1983, 48, 1829-1833.

[17] G. Piancatelli, A. Scettri, M. D'Auria, Tetrahedron Lett. 1977, $18,3483-3484$.
[18] E. M. Gonzalez-Garcia, J. Grognux, D. Wahler, J.-L. Reymond, Helv. Chim. Acta 2003, 86, 2458-2470. The Reymond protocol works perfectly by moving only one carbon atom farther from the neopentylic center (see ref. ${ }^{[12]}$ ).

[19] R. F. W. Jackson, R. A. Raphael, J. Chem. Soc. Perkin Trans. 1 1984, 535-539.

[20] It was anticipated that microwave assistance would be required to achieve ether formation in this highly hindered context. Model studies on previously synthesized $\mathbf{i}$ and ii showed that MW irradiation was required to best deal with this concern.

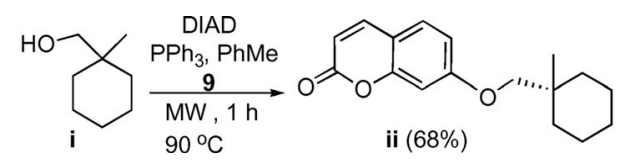

[21] For reviews on the use of microwaves in organic synthesis, see: a) C. O. Kappe, A. Stadler, Microwaves in Organic and Medicinal Chemistry, Wiley-VCH, Weinheim, 2005; b) C. O. Kappe, D. Dallinger, Drug Discovery 2006, 5, 51-63; c) A. de la Hoz, A. Diaz-Ortis, A. Moreno, F. Langa, Eur. J. Org. Chem. 2000, 3659-3673.

[22] This phenomenon is quite general as numerous examples are reported in the literature. G. Mehta, S. R. Kumaran, Tetrahedron Lett. 2003, 44, 7055-7059.

[23] a) N. Miyaura, A. Suzuki, Chem. Rev. 1995, 95, 2457-2483; b) S. R. Chemler, D. Trauner, S. J. Danishefsky, Angew. Chem. Int. Ed. 2001, 40, 4544 4568, and references cited therein.

[24] C. R. Johnson, M. P. Braun, J. Am. Chem. Soc. 1993, 115, 11014-11015.

[25] A. Corbu, M. Aquino, T. V. Pratap, P. Retailleau, S. Arseniyadis, Org. Lett. 2008, 10, 1787-1790.

[26] P. R. Rich, D. S. Bendall, Eur. J. Biochem. 1975, 55, 333-341.

[27] J. P. Bonfils, C. Bonfils, C. Larroque, J.-C. Baccou, Y. Sauvaire, Nat. Prod. Lett. 1995, 6, 15-22.

[28] a) M. S. Chen, M. C. White, Science 2007, 318, 783; b) N. A. Vermeulen, M. S. Chen, M. C. White, Tetrahedron 2009, 65, 3078-3084.

[29] A major issue, both in chemical and microbial oxidations, is how to divert oxidation away from the olefin to the desired unactivated $\mathrm{sp}^{3} \mathrm{C}-\mathrm{H}$ position.

[30] I. Bock, H. Bornowski, A. Ranft, H. Theis, Tetrahedron 1990, 46, 1199-1210.

Received: September 7, 2009 Published Online: 


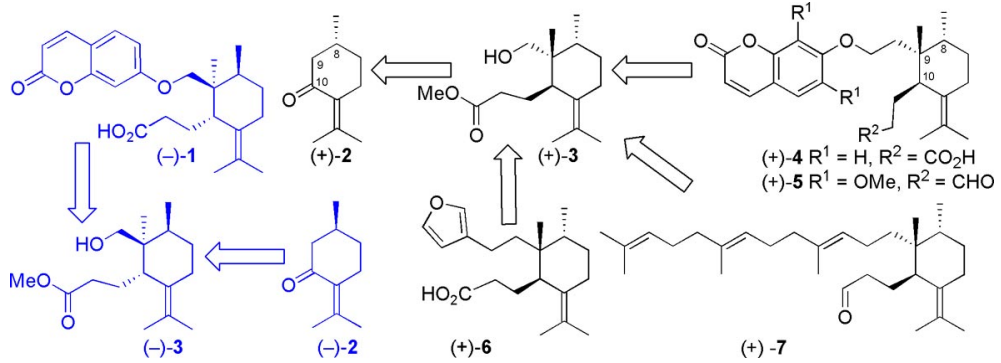

From readily available pulegone $\mathbf{2}$ (Mentha and various analogues have been synthepulegium, Pennyroyal), galbanic acid (Ferula asafetida), iridals (Iris germanica), sized via a common intermediate 3 by using the appropriate antipodes.

\section{A. Corbu, M. Aquino, M. Perez,}

Z. Gandara, S. Arseniyadis* 1-8

Natural and Unnatural A-seco Terpenes from Pulegone: Synthesis of Galbanic Acid and Marneral Revisited

Keywords: Terpenoids / Natural products / Chiral pool / Mitsunobu etherification / Microwave chemistry 